\title{
PRELIMINARY REPORT ON THE TAXONOMIC REVISION OF FOSSIL EQUIDAE FROM TIZI'N TADDERHT (OUARZAZATE, MOROCCO)
}

\author{
Omar Cirilli1 ${ }^{1}$ \& Samir Zouhri \\ ${ }^{1}$ Dipartimento di Scienze della Terra, Università degli Studi di Firenze 50121, Italy; omar.cirilli@yahoo.com \\ ${ }^{2}$ Laboratoire de géosciences, faculté des Sciences, Université Hassan II-Casablanca, Morocco; samirzouhri@yahoo.fr
}

\author{
KeYwORDS: \\ Hipparion; \\ Tizi'n Tadderth; \\ Sahabi; \\ Morocco; \\ Libya.
}

\section{Bullet-Points Abstract}

- The fossiliferous locality of Tizi'n Tadderht is a significant latest Miocene vertebrate fossil association in the North Africa.

- The fossil Equidae from Tizi'n Tadderht had been preliminarly studied (Zouhri et al. 2012).

- We prelimiarly revise the Tizi'n Tadderht Equidae association in order to have new insights on the genus Hipparion in Morocco.

\section{INTRODUCTION}

We are reviewing the sample of fossil Equidae, belonging to the genus "Hipparion" s.s. (see Armour-Chelu \& Bernor, 2011) from Tizi'n Tadderht (Ouarzazate, Morocco), a fossiliferous site chronologically referable to the Late Miocene.

The fossiliferous locality of Tizi'n Tadderht, already known in the literature (Geraads et al., 2012; Zouhri et al., 2012), has yielded a small but significant vertebrate fossil association. It represents the first documentation of a Late Miocene vertebrate fauna in the western area of North Africa. This new fauna allows to expand the possibilities of investigation on the biogeographical and evolutionary record of the vertebrate fossils in the circum-Mediterranean area.

\section{Materials and Methods}

The group of fossil Equidae under revision has been preliminarly studied by Zouhri et al. (2012), who identified the following hipparionini species: aff. Cremohipparion periafricanum (Villalta \& Crusafont, 1957), Hippotheriini gen. et sp. indet., and cf. Hippotherium primigenium (Von Meyer, 1829).

The sample retrieved from the considered area is under review through the description of the external anatomy morphologies and the dimensional measurements analysis. In addition, a comparison with the collection of fossil Equidae of the Libyan site of As Sahabi is also on the way. At As Sahabi the following species of Equidae hipparionini are represented (Bernor et al., 2008; 2012): Sivalhippus sp., Eurygnathohippus feibeli Bernor \& Harris, 2003 and Cremohipparion matthewi (Abel, 1926).

\section{Discussions}

This revision of the Tizi'n Tadderht association led us to confirm the identification of three hipparionine species, differing by size and anatomical details.

The largest form has been identified by Zouhri et al. (2012) as belonging to Hippotherium sp.; specimens referred to this taxon show some anatomical features suggesting an attribution to the genus Hippotherium Kaup, 1833, such as having all tooth elements isolated and not included in the cementum; a well developed mesostyle, complex plications of the pre- and postfossettes, an anterostyle more developed and isolated.

A medium-sized Equidae has been assigned to Hippotheriini gen. et sp. indet by Zouhri et al. (2012). The revision of the entire collection attributable to this midlle-sized hipparionine horse is under way. We are testing the hypothesis that such a form could be attributed to the genus Eurygnathohippus (Van Hoepen, 1930) (Fig. 1). This latter taxon is present within the fossil assemblage of As Sahabi (Libya) and Tizi'n Tadderht specimens are remarkably similar in dimensions and proportions to $E$. feibeli from the Libyan site.

Finally the few fragmentary fossils representing a very small hipparionine horse from Tizi'n Tadderht have been described by Zouhri et al. (2012) as Cremohipparion aff. $C$. periafricanum. Interestingly a very small hipparionine species also occurs in the Late Miocene site of As Sahabi (where it has been identified as Cremohipparion matthewi by Bernor et al., 2008). Our comparisons confirm the attribution of this small sample from Tizi'n Tadderht to the genus Cremohipparion Qiu et al., 1987. A deeper comparison with the As Sahabi sample is necessary before any conclusion for a determination at the specific level. 

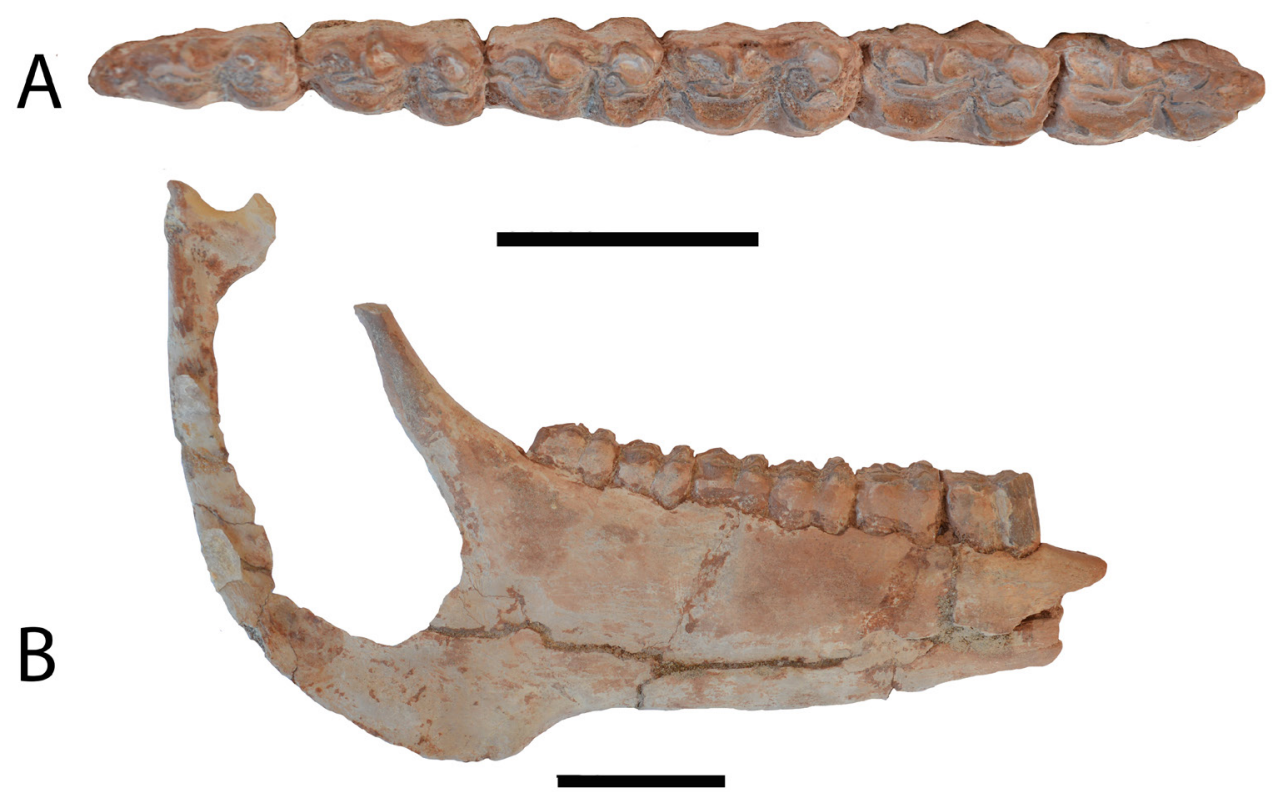

Fig. 1. Hippotheriini gen. et sp. indet from Tizi'n Tadderht - MTE 12, right hemimandible, A, p2-m3 in occlusal view. B, hemimandible in labial view. Scale bar $5 \mathrm{~cm}$.

\section{Conclusions}

The re-evaluation of the hipparionine equids assemblage from Tizi'n Tadderht site is of particular importance as it extends the paleogeographic record of Hipparion and other hipparionene species present in other African sites, showing that this clade is well represented in the African fossil record of the Late Miocene. At the same time, an exhaustive comparative study of the fossil Hipparionini assemblages from the As Sahabi site (Libya) and from Tizi'n Tadderht site (Morocco), will allow us to contrast similar contemporaneous faunal assemblages from the Late Miocene of North Africa and to have a better understanding of the development and the diffusion of Equidae assemblage during the Late Miocene in North Africa (as well as on the Late Miocene faunal exchange between Africa and Europe).

\section{REFERENCES}

Abel O. (1926). Die Geschichte der Equiden auf dem Bodem Noramerikas. Verhandlungen Zoologish-Botanischen Gesellschaft, 74: 159-164

Armour-Chelu M. \& Bernor R. L. (2011). Equidae. In Harrison T. (ed.), Paleontology and geology of Laetoli: Human evolution in context (Fossil hominins and the associated fauna, Vol. 2), Springer, Dordrecht: 295-326.

Bernor R. L. \& Harris J. M. (2003). Systematics and evolutionary biology of the Late Miocene and Early Pliocene hipparionine horses from Lothagam, Kenya. In Harris J.M. \& Leakey M.G. (eds), Lothagam: The Dawn of Humanity in Eastern Africa, Columbia University Press, New York: 387-438.
Bernor R. L., Kaiser T. M. \& Wolf D. (2008). Revisiting Sahabi equid species diversity, biogeographic patterns and diet preferences. In El-Arnauti A., Salem M., Pavlakis P. \& Boaz N. (eds), Circum- Mediterranean Geology and Biotic Evolution During the Neogene Period: The Perspective from Libya. Garyounis Scientific Bulletin, Special Issue, 5: 159-167.

Bernor R. L., Boaz N. T. \& Rook L. (2012) Eurygnathohippus feibeli (perissodactyla: Mammalia) from the Late Miocene of As Sahabi (Libya) and its Evolutionary and Biogeographic Significance. Bollettino della Società Paleontologica Italiana, 51 (1), 39-48.

Geraads D., El Boughabi S. \& Zouhri S. (2012). A new caprin bovid (Mammalia) from the late Miocene of Morocco. Paleontologia africana, 47:19-24.

Kaup J. J. (1833). Mitteilungen an Professor Bronn. Neues Jahrbuch fur Mineralogie, Geognoise, Geologie und Petrefaktenkunde Jahrgang, 1833: 419-420.

Qui Z. X., Huang W. L. \& Guo Z. H. (1987). The Cinese hipparionine fossils. Paleontologia Sinica, New Series 25: 1-150.

Van Hoepen E. C. N. (1930). Fossiele Pferde van Cornelia. Paleontologiese Navorsing van die Nasionale Museum, Bloemfontein, 2: 13-24.

Villalta, J. F. \& Crusafont, M. (1957). Les gisements de mammifères du Néogène espagnol. Comptes Rendus de la Société Géologique de France, 9-10.

Von Meyer H.1829. Taschenbuch für die gesamte Mineralogie. Zeitschrift Mineralien, 23: 150-152.

Zouhri S., Geraads D., El Boughabi S. \& El Harfi A. (2012). Discovery of an Upper Miocene Vertebrate fauna near Tizi N'Tadderht, Skoura, Ouarzazate Basin (Central High atlas, Morocco). Comptes Rendus Palevol, 11: 455461.

Manuscript received 30 July 2018

Received after revision 28 September 2018

Accepted 1 October 2018 